\title{
Intravenous tissue plasminogen activator treatment for ischemic stroke in dabigatran-treated patients
}

\author{
Satoru Takeuchi • Kojiro Wada • Kimihiro Nagatani • \\ Naoki Otani • Hideo Osada $\cdot$ Hiroshi Nawashiro
}

Received: 12 August 2011 / Accepted: 27 September 2011 /Published online: 25 October 2011

(C) Springer-Verlag 2011

Vergouwen et al. reported that intravenous tissue plasminogen activator (IV tPA) treatment was not associated with an increased risk of secondary intracerebral hemorrhage or gastrointestinal hemorrhage in patients with acute ischemic stroke taking warfarin with an international normalized ratio (INR) $<1.7$ [6]. These results mean that IV tPA treatment should not be discouraged in patients taking warfarin with INR $<1.7$.

Recently, dabigatran, a new oral anticoagulant, was approved by the FDA. In the Randomized Evaluation of Long-Term Anticoagulant Therapy trial, dabigatran was shown to be as effective as warfarin in prevention of systemic embolism and future stroke, with lower risk of major hemorrhage [2]. Additionally, dabigatran does not need monitoring (differently from warfarin). Therefore, the number of dabigatran-treated patients presenting with ischemic stroke may increase in the future. However, there is no guideline whether dabigatran-treated patients presenting with ischemic stroke can be considered eligible for IV tPA treatment or not. Only two case reports demonstrated the safety of IV tPA treatment for acute ischemic stroke in dabigatran-treated patient $[3,5]$. On the other hand, Ammollo et al. reported that dabigatran enhanced the susceptibility of plasma clots to tPA-induced lysis in in vitro study [1]. Based on Ammollo's results, we can hypothesize that dabigatran may also enhance the bleeding risk caused by tPA.

Although we recognize the lack of data on IV tPA treatment for acute ischemic stroke in dabigatran-treated

S. Takeuchi $(\bowtie) \cdot$ K. Wada $\cdot$ K. Nagatani $\cdot$ N. Otani $\cdot$ H. Osada $\cdot$ H. Nawashiro

Department of Neurosurgery, National Defense Medical College, 3-2 Namiki,

Tokorozawa, Saitama 359-8513, Japan

e-mail: s.takeuchi@room.ocn.ne.jp patients, we need provisional guidelines of the topic, as early as possible, in order to avoid confusion. Some tests, such as activated partial thrombin time and ecarin clotting time, which have been reported as correlated with dabigatran concentrations, can be helpful for clinicians to determine the indication of IV tPA for such patients [4].

Conflicts of interest None.

\section{References}

1. Ammollo CT, Semeraro F, Incampo F, Semeraro N, Colucci M (2010) Dabigatran enhances clot susceptibility to fibrinolysis by mechanisms dependent on and independent of thrombin-activatable fibrinolysis inhibitor. Thromb Haemost 8:790-798

2. Connolly SJ, Ezekowitz MD, Yusuf S, Eikelboom J, Oldgren J, Parekh A, Pogue J, Reilly PA, Themeles E, Varrone J, Wang S, Alings M, Xavier D, Zhu J, Diaz R, Lewis BS, Darius H, Diener HC, Joyner CD, Wallentin L, RE-LY Steering Committee and Investigators (2009) Dabigatran versus warfarin in patients with atrial fibrillation. N Engl J Med 361:1139-1151

3. De Smedt A, De Raedt S, Nieboer K, De Keyser J, Brouns R (2010) Intravenous thrombolysis with recombinant tissue plasminogen activator in a stroke patient treated with dabigatran. Cerebrovasc Dis 30:533-534

4. Liesenfeld KH, Schäfer HG, Trocóniz IF, Tillmann C, Eriksson BI, Stangier J (2006) Effects of the direct thrombin inhibitor dabigatran on ex vivo coagulation time in orthopaedic surgery patients: a population model analysis. Br J Clin Pharmacol 62:527-537

5. Matute MC, Guillán M, García-Caldentey J, Buisan J, Aparicio M, Masjuan J, Alonso de Leciñana M (2011) Thrombolysis treatment for acute ischaemic stroke in a patient on treatment with dabigatran. Thromb Haemost 106:178-179

6. Vergouwen MD, Casaubon LK, Swartz RH, Fang J, Stamplecoski M, Kapral MK, Silver FL, Investigators of the Registry of the Canadian Stroke Network (2011) Subtherapeutic warfarin is not associated with increased hemorrhage rates in ischemic strokes treated with tissue plasminogen activator. Stroke 42:1041-1045 